\title{
PENGARUH EFEKTIFITAS E-TICKETING DAN PROMOSI ON-LINE TERHADAP PENINGKATAN VOLUME PENJUALAN PT. CITILINK INDONESIA DI BANDARA HALIM PERDANAKUSUMA
}

\author{
Sri Yanthy Yosepha dan Galuh Diah Pitaloka \\ yosephariyanto09@gmail.com \& vgadipita@gmail.com
}

\section{Abstract}

Citilink is one of the Low Cost Carrier airlines in Indonesia, providing customers with options for cheap and quality flights that make it easier for customers to reach their destination. But With the rapid increase of the air transport industry nowadays that have implemented internet service in marketing strategy such as e-ticketing and promotion online make the competition between companies more tight in grabbing customers and maintaining existing market share. Citilink is one airline service company since 2012 has implemented e-ticketing and online promotion to achieve sales volume increase target. The e-ticketing and online promotion system is a marketing strategy that brings marketers and consumers closer together, the ease of consumers to interact effectively and efficiently at the end of the consumer's benefit and then repurchase and recommend to friends, relatives and family to buy and use information interactive through online facilities. Based on this background, the formulation of the problem This study aims to determine (1) is there any effect of e-Ticketing effectiveness partially on the increase of sales volume, (2) is there any influence of partial online promotion on sales volume increase, (3) is there any effect of e-and simultaneous online promotion of increased sales volume. The method used is accumulated sampling with 100 respondents using Citilink at Halim Perdanakusuma Airport.

The results obtained by multiple linear regression equation is $Y=0.909+0.404 X_{1}+0.101 X_{2}$, indicating that the Effectiveness of E-ticketing and online promotion have a positive and significant impact on the increase of sales volume. Partial test ( $t$ test) e-ticketing effectiveness is $Y^{1}=3.435+0.513 X_{1}$ shows that Effectiveness of E-ticketing have a positive and significant impact to the increase of sales volume. Partial test (t test) online promotion is $Y^{I}=5.719+0.329 X_{2}$. shows that online promotion has a positive and significant impact on sales volume increase.

Keywords: effectiveness of e-ticketing, online promotion, increase in sales volume

\section{PENDAHULUAN}

\section{a. Latar Belakang Masalah}

Perkembangan transportasi udara pada abad dua puluh satu semakin pesat dan mobilitas manusia serta letak geografis Indonesia yang tersebar menuntut dunia industri penerbangan mampu menyediakan layanan jasa penerbangan dengan cepat, aman dan nyaman sesuai dengan permintaan konsumen. Tidak heran jika bisnis penerbangan di Indonesia semakin subur seiring dengan adanya permintaan pasar yang terus meningkat.

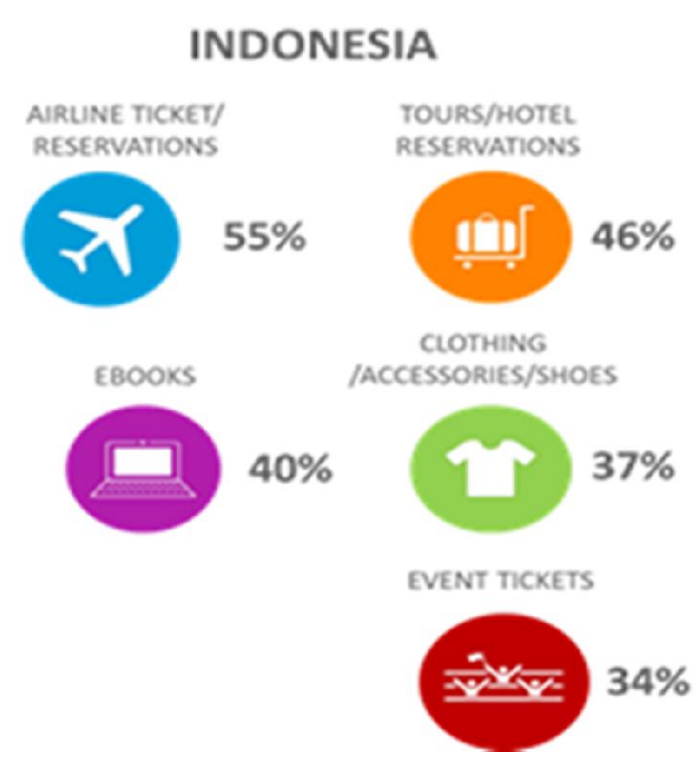


Konsumen memilih untuk menggunakan pesawat terbang bukan lagi sebuah hal yang dapat dilakukan kalangan kelas atas saja, apalagi sekarang semua perusahaan jasa penerbangan berlomba untuk memberikan layanan biaya murah.

Layanan biaya murah memberikan peluang kepada masyarakat untuk menggunakan moda transportasi udara, pada Gambar 1.1. tersebut diatas menunjukkan hasil survey yang dilakukan Nielsen Global Survey of E-commerce, 2014, bahwa hampir 55\% masyarakat keinginan membeli airfare ticket/tiket pesawat udara, $46 \%$ masyarakat memiliki keinginan melakukan tours/reservation hotel, $40 \%$ masyarakat memiliki keinginan untuk membeli e-books, $37 \%$ masyarakat memiliki keinginan membeli baju/asesoris/sepatu, dan 34\% masyarakat memiliki keinginan membeli tiket konser musik. Dengan gambaran hasil survey tersebut perlu dilakukan antisipasi terhadap lonjakan penumpang pesawat udara agar tidak terjadi penumpukan jumlah penumpang dibandara, antisipasi yang dilakukan oleh perusahaan jasa penerbangan yaitu merubah layanan konvensional ke modern. Perubahan ini banyak dipengaruhi oleh semakin berkembangnya teknologi. Menurut Rambat Lupiyoadi pada buku Manajemen Pemasaran Jasa, 2014: penerapan teknologi menghasilkan revolusi.

Tabel 1.1.

Data Pengguna Internet di Beberapa Pulau Indonesia Tahun 2016

\begin{tabular}{|l|c|c|c|}
\hline \multicolumn{1}{|c|}{ Nama Kota } & $\begin{array}{c}\text { Populasi Total } \\
\text { (Jiwa) }\end{array}$ & $\begin{array}{c}\text { Pengguna Internet } \\
\text { (Jiwa) }\end{array}$ & $\begin{array}{c}\text { Penetrasi Pengguna } \\
\text { Internet (\%) }\end{array}$ \\
\hline Jawa & 145.143 .600 & 86.339 .350 & 63 \\
\hline Sumatera & 55.272 .900 & 20.752 .185 & 15,7 \\
\hline Bali \& Nusa & 14.108 .500 & 6.148 .792 & 4,7 \\
\hline Kalimantan & 15.343 .000 & 7.685 .992 & 5,8 \\
\hline Sulawesi & 18.724 .000 & 8.454 .592 & 6,3 \\
\hline Maluku \& Papua & 6.869 .700 & 3.330 .596 & 2,5 \\
\hline
\end{tabular}

Sumber: APJII 2016

Perusahaan jasa penerbangan di Indonesia hampir semua sudah menerapkan teknologi pada setiap kegiatan perusahaan terutama pemasaran. Penggunaan internet pada saat ini terutama di Indonesia paling diminati oleh semua orang karena kemudahannya seperti kemudahan informasi, interaksi baru, dan market place baru. Dan hal ini didukung dengan hasil survei yang dilakukan APJII mencapai angka 65 juta pengguna internet dari 256,2 juta penduduk Indonesia. Pengguna internet di Pulau Jawa tahun 2016 
sebesar 86,3 Juta atau sekitar $63 \%$ seperti dapat dilihat pada tabel 1.1. tersebut diatas. Internet telah dipersepsikan sebagai media yang tepat untuk sarana komunikasi dengan konsumen secara langsung menciptakan lingkungan bisnis online yang interaktif, pemanfaatan internet menyebabkan kebiasaan baru dalam segala aspek kehidupan.

Pada awalnya penerapan pembelian tiket secara online sekitar tahun 1998 hanya mencapai satu persen lalu naik menjadi dua persen pada tahun 1999. Saat ini sudah mencapai tiga persen. Persentase tersebut berlipat ganda pada maskapai Amerika Serikat, United Airlines, dimana lima persen dari pendapatan penerbangan domestiknya pada kwartal pertama tahun ini merupakan sumbangan online sales dengan pertimbangan 50-50 antara website dan lain-lain.

Dengan perkembangan distribusi informasi online yang semakin bergerak dengan cepat, PT. Citilink melakukan berbagai gebrakan gebrakan untuk mengikuti trend era digitalisasi dengan penerapan sistem $e-$ ticketing. Namun dalam proses penerapan tidak serta merta layanan e-ticketing yang diberikan oleh PT. Citilink dapat diketahui dan diterima oleh konsumen, konsumen belum begitu mengenal PT. Citilink dengan baik walaupun ini merupakan unit bisnis dari PT. Garuda.

Penerapan e-ticketing yang dilakukan Citilink selain untuk meningkatkan volume penjualan dan juga upaya membuat penumpang menggunakan dan memilih kembali maskapai penerbangan Citilink diluar segala berita kemiringan mengenai kecelakaan kecil atau persaingan antara maskapai penerbangan.

Promosi online merupakan sarana yang digunakan perusahaan untuk menginformasikan, membujuk, mengingatkan konsumen, membangun berbagai saluran informasi dan persuasi tentang barang dan jasa yang mereka jual melalui media internet.

\section{b. Rumusan Masalah}

Berdasarkan latar belakang masalah yang telah diuraikan sebelumnya, maka penulis merumuskan permasalahan dalam penelitian ini sebagai berikut:

1. Adakah pengaruh efektifitas e-ticketing $\left(\mathrm{X}_{1}\right)$ secara parsial terhadap peningkatan volume penjualan $(\mathrm{Y})$ ?

2. Adakah pengaruh promosi online $\left(\mathrm{X}_{2}\right)$ secara parsial terhadap peningkatan volume penjualan $(\mathrm{Y})$ ?

3. Adakah pengaruh efektifitas e-ticketing $\left(\mathrm{X}_{1}\right)$ dan promosi online $\left(\mathrm{X}_{2}\right)$ secara simultan terhadap peningkatan volume penjualan $(\mathrm{Y})$ ?

\section{c. Tujuan Penelitian}

1. Untuk mengetahui pengaruh efektifitas e-ticketing terhadap peningkatan volume penjualan; 
2. Untuk mengetahui pengaruh promosi online terhadap peningkatan volume penjualan;

3. Untuk mengetahui pengaruh efektifitas e-ticketing dan promosi online terhadap peningkatan volume penjualan.

\section{TINJAUAN PUSTAKA}

\section{a. Efektifitas Media Internet}

Komunikasi yang dilakukan dapat dikatakan efektif jika sebagai komunikator berhasil menyampaikan suatu pesan. Komunikasi yang efektif adalah apabila penerima menginterpretasikan pesan yang diterimanya sebagaimana dimaksudkan oleh Andre Hardjana : 2000, hal 23-24 pada buku Audit Komunikasi: Teori dan Praktek (ISBN: 979669-809-9) menjelaskan

efektifitas

komunikasi sebagai berikut:

(1) Penerima/pemakai: penerima pesan versus penerima yang dituju, mereka yang menjadi tujuan atau sasaran muatan pesan untuk dipahami;

(2) Isi Pesan: yang diterima/tersalur versus yang dimaksudkan, hal yang disampaikan kepada penerima.

(3) Ketepatan waktu: sesuai jadwal versus menyimpang jadwal: Sesuai jadwal, pesan yang dimaksudkan sampai kepada penerima pesan tepat pada waktunya artinya penyampaian pesan tersebut sesuai dengan kondisi dan waktu.
(4) Media: saluran yang digunakan versus saluran yang dimaksud saluran atau alat yang digunakan untuk menyampaikan pesan sesuai dengan kebutuhan dan diharapkan oleh pengirim dan penerima pesan.

(5) Format: struktur yang diterima versus struktur yang dikirim; terdapat kesamaan format antara yang dimaksudkan oleh pengirim dengan penerima.

(6) Sumber: orang yang melakukan versus yang bertanggung jawab; apakah kejelasan sumber yang dapat dipertanggung jawabkan sehingga pesan yang disampaikan akurat.

\section{b. Pengertian E-ticketing E-ticketing}

E-ticketing adalah suatu cara untuk mendokumentasikan proses penjualan dari aktifitas perjalanan pelanggan tanpa harus mengeluarkan dokumen berharga secara fisik ataupun paper ticket. Semua informasi mengenai e-ticketing disimpan secara digital dalam sistem komputer milik perusahaan penerbangan. Sebagai bukti pengeluaran $e$ ticketing, pelanggan akan diberikan itinerary receipt yang hanya berlaku sebagai alat untuk masuk ke dalam bandara di Indonesia yang masih mengharuskan penumpang untuk membawa tanda bukti perjalanan. Eticketing adalah peluang untuk meminimalkan biaya dan mengoptimalkan kenyamanan penumpang. e-ticketing mengurangi biaya proses tiket, 
menghilangkan fomulir kertas dan meningkatkan fleksibilitas penumpang.

\section{c. Pengertian Promosi Online}

Promosi online sebagai sarana promosi melalui internet yang telah diterapkan hampir seluruh perusahaan maskapai penerbangan. Pertumbuhan perkembangan teknologi promosi online telah memicu antusiasme untuk mengembangkan promosi pelanggan responsif (Chatterjee \& McGinnis, 2010). Sedangkan menurut Pribadi (2010,p3), promosi online adalah kegiatan berpromosi yang dilakukan menggunakan media internet dengan segala kelebihannya, antara lain: multimedia, interaktif, dan realtime. Dan menurut Salim $(2010,1)$ pengertian promosi online: sebuah upaya atau usaha untuk mempromosikan sesuatu melalui media internet dimana akan diperuntukkan bagi siapapun yang sudah memiliki produk. Produk tersebut bisa berupa took online, bisnis online, atau juga eventevent. Produk tersebut dipromosikan melalui internet supaya ada begitu banyak orang yang mengetahuinya dan pada akhirnya mengikuti instruksi yang disampaikan melalui pesanpesan promosi tersebut.

\section{d. Pengertian Volume Penjualan}

Volume penjualan merupakan hasil akhir yang dicapai perusahaan dari hasil penjualan produk yang dihasilkan oleh perusahaan tersebut. Volume penjualan tidak memisahkan secara tunai maupun kredit tetapi dihitung secara keseluruhan dari total yang dicapai. Seandainya volume penjualan meningkat dan biaya distribusi menurun maka tingkat pencapaian laba perusahaan meningkat tetapi sebaliknya bila volume penjualan menurun maka pencapaian laba perusahaan juga menurun. Menurut Kotler (2000) volume penjualan adalah barang yang terjual dalam bentuk uang untuk jangka waktu tertentu dan didalamnya mempunyai strategi pelayanan yang baik. Ada beberapa usaha untuk meningkatkan volume penjualan, diantaranya adalah :

1) Menjajakan produk dengan sedemikian rupa sehingga konsumen melihatnya.

2) Menempatkan dan pengaturan yang teratur sehingga produk tersebut akan menarik perhatian konsumen.

3) Mengadakan analisa pasar.

4) Menentukan calon pembeli atau konsumen yang potensial.

5) Mengadakan pameran.

6) Mengadakan discount atau potongan harga.

Volume penjualan dapat dijabarkan sebagai umpan balik dari kegiatan pemasaran yang dilaksanakan oleh perusahaan. Penjualan mempunyai pengertian yang bermacam-macam tergantung pada lingkup permasalahan yang sedang dibahas. Menurut Swastha dan Irawan (2000), permintaan pasar dapat diukur dengan menggunakan volume fisik maupun volume rupiah. Berdasarkan pendapat Swastha dan Irawan tersebut, pengukuran volume penjualan dapat 
dilakukan dengan dua cara, yaitu didasarkan jumlah unit produk yang terjual dan didasarkan pada nilai produk yang terjual (omzet penjualan). Volume penjualan yang diukur berdasarkan unit produk yang terjual, yaitu jumlah unit penjualan nyata perusahaan dalam suatu periode tertentu, sedangkan nilai produk yang terjual (omzet penjualan), yaitu jumlah nilai penjualan nyata perusahaan dalam suatu periode tertentu. Dalam penelitian ini pengukuran volume penjualan didasarkan pada jumlah unit dan nilai produk yang terjual.

\section{METODOLOGI PENELITIAN}

\section{a. Tempat penelitian}

Lokasi penelitian di Bandara Halim Perdanakusuma yang merupakan salah satu titik terbang dari maskapai penerbangan Citilink Indonesia, dengan mempertimbangkan perolehan data yang terkait dengan penelitian dan pengumpulan data.

\section{b. Populasi dan sample}

Populasi dalam penelitian ini yaitu penumpang yang menggunakan City link di Halim Perdanakusuma Jakarta, teknik pengambilan sampel yang digunakan adalah Insidental Sampling yaitu dengan mengambil responden yang ada atau tersedia sebanyak 100 responden.

\section{c. Jenis data}

Jenis penelitian yang dipergunakan adalah deskriptif yaitu metode kuantitatif yang bertujuan membuat kalimat (deskriptif) secara sistematis, factual dan akurat mengenai fakta-fakta dari sifat populasi yang terukur (angka-angka). Metode yang digunakan unuk memperoleh hasil analisis yang disusun secara sistematis. Penggalian data diguanakan melalui kuesioner dengan kategori skala nominal.

\section{d. Teknik Pengumpulan Data}

Teknik pengolahan data yang digunakan dalam penelitian ini adalah dengan melakukan pengukuran terhadap variabel independen dan varibel dependen. Alat ukur yang digunakan adalah dengan menggunakan Skala Likert yaitu skala yang digunakan untuk mengukur sikap, pendapat dan persepsi seseorang atau kelompok orang tentang fenomena sosial (Sugiyono, 2005:86). Setelah itu data yang dikumpulkan di buatkan tabulasi dengan menggunakan komputer pada program Spss versi 22.

\section{ANALISIS DATA}

\section{Uji Validitas}

Validitas adalah suatu ukuran yang menunjukkan bahwa variabel yang diukur benar-benar variabel yang hendak diteliti oleh peneliti (Cooper dan Schindler, dalam Zulganef, 2006). 
Tabel 1

Hasil Uji Validitas

\begin{tabular}{|c|c|c|c|}
\hline $\begin{array}{c}\text { No } \\
\text { Pernyataann }\end{array}$ & $\mathbf{r}$ hitung & $\mathbf{r}$ tabel & Keterangan \\
\hline \multicolumn{4}{|c|}{ Efektivitas E-ticketing ( $\left.\mathrm{X}_{1}\right)$} \\
\hline 1 & 0.267 & 0.1966 & Valid \\
\hline 2 & 0.450 & 0.1966 & Valid \\
\hline 3 & 0.365 & 0.1966 & Valid \\
\hline 4 & 0.458 & 0.1966 & Valid \\
\hline 5 & 0.413 & 0.1966 & Valid \\
\hline 6 & 0.272 & 0.1966 & Valid \\
\hline 7 & 0.335 & 0.1966 & Valid \\
\hline 8 & 0.475 & 0.1966 & Valid \\
\hline 9 & 0.300 & 0.1966 & Valid \\
\hline \multicolumn{4}{|c|}{ Promosi Online } \\
\hline 1 & 0.211 & 0.1966 & Valid \\
\hline 2 & 0.449 & 0.1966 & Valid \\
\hline 3 & 0.347 & 0.1966 & Valid \\
\hline 4 & 0.411 & 0.1966 & Valid \\
\hline 5 & 0.270 & 0.1966 & Valid \\
\hline 6 & 0.328 & 0.1966 & Valid \\
\hline 7 & 0.263 & 0.1966 & Valid \\
\hline 8 & 0.352 & 0.1966 & Valid \\
\hline 9 & 0.292 & 0.1966 & Valid \\
\hline 10 & 0.201 & 0.1966 & Valid \\
\hline 11 & 0.301 & 0.1966 & Valid \\
\hline 12 & 0.331 & 0.1966 & Valid \\
\hline 13 & 0.316 & 0.1966 & Valid \\
\hline 14 & 0.358 & 0.1966 & Valid \\
\hline \multicolumn{4}{|c|}{ Peningkatan Volume Penjualan } \\
\hline 1 & 0.591 & 0.1966 & Valid \\
\hline 2 & 0.312 & 0.1966 & Valid \\
\hline 3 & 0.496 & 0.1966 & Valid \\
\hline 4 & 0.413 & 0.1966 & Valid \\
\hline 5 & 0.255 & 0.1966 & Valid \\
\hline
\end{tabular}

Dari uji validitas yang telah dilakukan pada variabel Efektivitas E-Ticketing dan Promosi On-line terhadap Peningkatan Volume Penjualan dapat ditarik kesimpulan bahwa seluruh item pernyataan dalam variabel tersebut valid karena memiliki $\mathrm{r}_{\text {hitung }}>\mathrm{r}_{\text {tabel. }}$

\section{Uji Realiabilitas}

Tabel 2

Hasil Uji Realibitas

\begin{tabular}{|c|l|c|c|c|}
\hline No & \multicolumn{1}{|c|}{ Variabel } & $\begin{array}{c}\text { Nilai } \\
\text { Alpha }\end{array}$ & $\begin{array}{c}\text { Tingkat } \\
\text { Kehandalan }\end{array}$ & Keterangan \\
\hline 1. & $\begin{array}{l}\text { Efektivitas } \\
\text { E-ticketing }\end{array}$ & 0.691 & 0.6 & Reliabel \\
\hline 2. & $\begin{array}{l}\text { Promosi } \\
\text { Online }\end{array}$ & 0.695 & 0.6 & Reliabel \\
\hline 3. & $\begin{array}{l}\text { Peningkatan } \\
\text { Penjualan }\end{array}$ & 0.650 & 0.6 & Reliabel \\
\hline
\end{tabular}

Berdasarkan hasil uji reliabilitas yang telah dilakukan untuk semua variabel, di dapatkan skor cronbach's alpha untuk Efektivitas Eticketing $\left(\mathrm{X}_{1}\right)$ dan Promosi Online serta Peningkatan Penjualan secara berurutan sebesar $0.691,0.695,0.650$. Hal ini berarti pernyataan dari ketiga variabel tersebut dinyatakan reliabel karena nilai cronbach's alpha lebih besar dari tingkat kehandalan yaitu sebesar 0.6.

\section{Uji Normalitas}

Uji normalitas berfungsi untuk mengetahui apakah data yang diambil adalah data yang terdistribusi normal, maksud dari terdistribusi normal adalah bahwa data akan mengikuti bentuk distribusi normal dimana datanya memusat pada nilai rata rata median (Sugiyono, 2007;138). Uji normalitas bergunaa untuk mengetahui apakah variabel bebas dan variabel terikat dalam penelitian ini keduanya terdistribusi normal, mendekati normal atau tidak. Uji normalitas pada penelitian ini menggunakan Uji histogram dan uji normal $\mathrm{P}$ Plot. Normalitas dapat dideteksi dengan melihat penyebaran data 
(titik) pada sumbu diagonal dari grafik atau dengan melihat histogram residualnya.

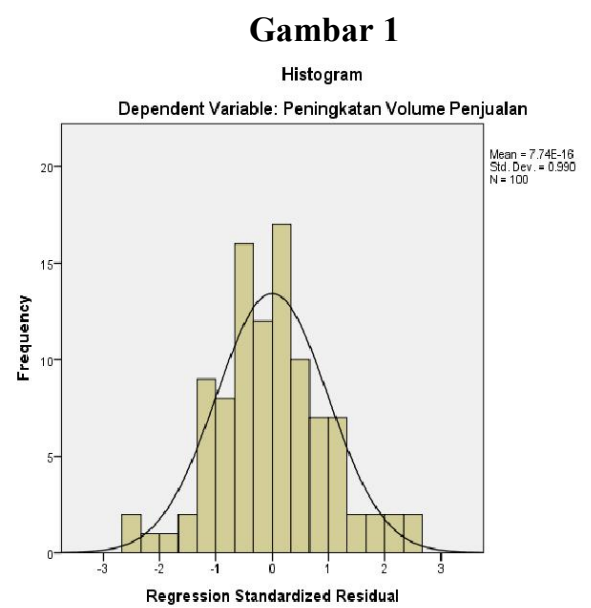

Gambar 2

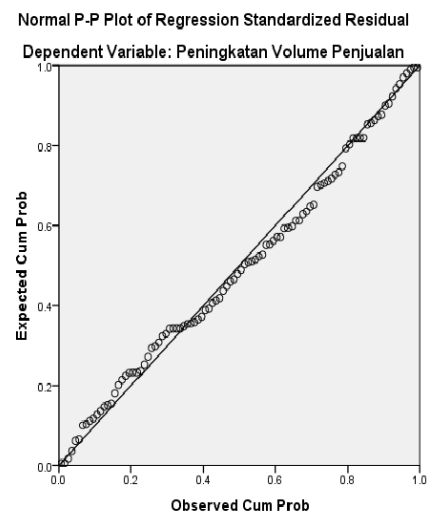

Hasil uji normalitas Gambar 1 dengan menggunakan uji histogram dan Gambar 2 dengan menggunakan uji normal B-Plot diatas menunjukkan bahwa grafik histogramnya menunjukkan pola distribusi normal dan data menyebar disekitar garis diagonal dan mengikuti arah garis diagonal, maka model regresi memenuhi asumsi normal, dapat disimpulkan bahwa data variabel pengaruh efektivitas e-ticketing, promosi online dan peningkatan volume penjualan dinyatakan distribusi normal.

\section{Hasil Uji Linearitas}

Uji Linearitas bertujuan untuk mengetahui apakah dua variabel mempunyai hubungan yang linear atau tidak secara signifikan. Uji linearitas biasanya digunakan sebagai prasyaratan dalam analisis korelasi atau regresi linear. 
Tabel 3

Hasil Uji Linearitas Variabel Pengaruh Efektivitas E-Ticketing dengan Variabel Peningkatan Volume Penjualan

\begin{tabular}{|c|c|c|c|c|c|c|c|}
\hline & & & $\begin{array}{l}\text { Sum of } \\
\text { Squares }\end{array}$ & df & $\begin{array}{l}\text { Mean } \\
\text { Square }\end{array}$ & $\mathrm{F}$ & Sig. \\
\hline \multirow{5}{*}{$\begin{array}{l}\text { Peningkatan Volume } \\
\text { Penjualan * Pengaruh } \\
\text { Efektivitas E-ticketing }\end{array}$} & Between & (Combined) & 576.783 & 18 & 32.043 & 9.634 & .000 \\
\hline & Groups & Linearity & 514.006 & 1 & 514.006 & 154.541 & .000 \\
\hline & & $\begin{array}{c}\text { Deviation from } \\
\text { Linearity }\end{array}$ & 62.777 & 17 & 3.693 & 1.110 & .359 \\
\hline & \multicolumn{2}{|c|}{ Within Groups } & 269.407 & 81 & 3.326 & & \\
\hline & \multicolumn{2}{|r|}{ Total } & 846.190 & 99 & & & \\
\hline
\end{tabular}

Sumber: Data Primer diolah tahun 2017

Berdasarkan hasil uji linearitas pada di atas diketahui nilai signifikansi linearitas data tersebut adalah sebesar 0.000 lebih kecil dari 0.05 dan nilai signifikansi deviasi from linearity data tersebut adalah sebesar 0.359 lebih besar dari 0.05. Jadi dapat disimpulkan bahwa antara variabel pengaruh efektivitas e-ticketing dan peningkatan volume penjualan memiliki hubungan linear.

Tabel 4

Hasil Uji Linearitas Variabel Promosi Online Dengan Variabel Peningkatan Volume Penjualan

\begin{tabular}{|c|c|c|c|c|c|c|c|}
\hline \multicolumn{8}{|c|}{ ANOVA Table } \\
\hline & & & $\begin{array}{l}\text { Sum of } \\
\text { Squares }\end{array}$ & $\mathrm{df}$ & $\begin{array}{c}\text { Mean } \\
\text { Square }\end{array}$ & $\mathrm{F}$ & Sig. \\
\hline \multirow{5}{*}{$\begin{array}{c}\text { Peningkatan } \\
\text { Volume Penjualan } \\
* \text { Promosi Online }\end{array}$} & Between & (Combined) & 346.972 & 22 & 15.771 & 2.433 & .002 \\
\hline & Groups & Linearity & 294.576 & 1 & 294.576 & 45.436 & .000 \\
\hline & & $\begin{array}{c}\text { Deviation from } \\
\text { Linearity }\end{array}$ & 52.396 & 21 & 2.495 & .385 & .992 \\
\hline & & hin Groups & 499.218 & 77 & 6.483 & & \\
\hline & & Total & 846.190 & 99 & & & \\
\hline
\end{tabular}

Sumber: Data Primer diolah tahun 2017

Berdasarkan hasil uji linearitas pada tabel di atas diketahui nilai signifikansi linearitas data tersebut adalah sebesar 0.000 lebih kecil dari 0.05 dan nilai signifikansi deviasi from linearity data tersebut adalah sebesar 0.992 lebih besar dari 0.05. Jadi dapat disimpulkan bahwa antara variabel promosi online dan peningkatan volume penjualan memiliki hubungan linear.

\section{Uji Multikolinearitas}

Uji multikolinearitas berguna untuk mengetahui apakah pada model regresi yang diajukan telah ditemukan korelasi kuat antar variabel bebas. Mengukur multikolinearitas dapat diketahui dengan melihat nilai Variance Inflation Factor (VIF) pada model regresi. Jika besar VIF $<5$ atau mendekati 1, maka mencerminkan tidak ada multikolinearitas (Husein Umar, 2008:80). 
Tabel 5

Hasil Uji Multikolinearitas

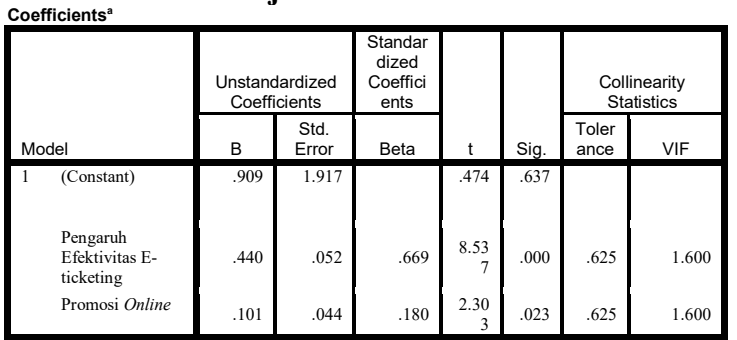

ependent Variable: Kepuasan_Pelanggan

Berdasarkan tabel di atas hasil uji multikolinearitas diketahui nilai Variance Inflation factor (VIF) untuk variabel Pengaruh Efektivitas E-ticketing $\left(\mathrm{X}_{1}\right)$ dan Promosi Online $\left(\mathrm{X}_{2}\right)$ yakni sebesar 1.600 lebih kecil dari 10.00, dan nilai tolerance Pengaruh Efektivitas E-ticketing $\left(\mathrm{X}_{1}\right)$ dan Promosi Online $\left(\mathrm{X}_{2}\right)$ yakni 0.625 lebih besar dari 0.10 , sehingga dapat disimpulkan tidak terjadi multikolinearitas.

\section{Uji Heteroskedasitas}

Uji heteroskedastisitas dilakukan untuk mengetahui apakah dalam sebuah model regresi terjadi ketidaksamaan varian dari residual suatu pengamatan kepengamatan lain. Jika varian dari residual suatu pengamatan kepengamatan lain tetap, disebut homokedastisitas, sedangkan untuk varian yang berbeda disebut heteroskedastisitas.
Tabel 6

Hasil Uji Heteroskedasitas

Correlations

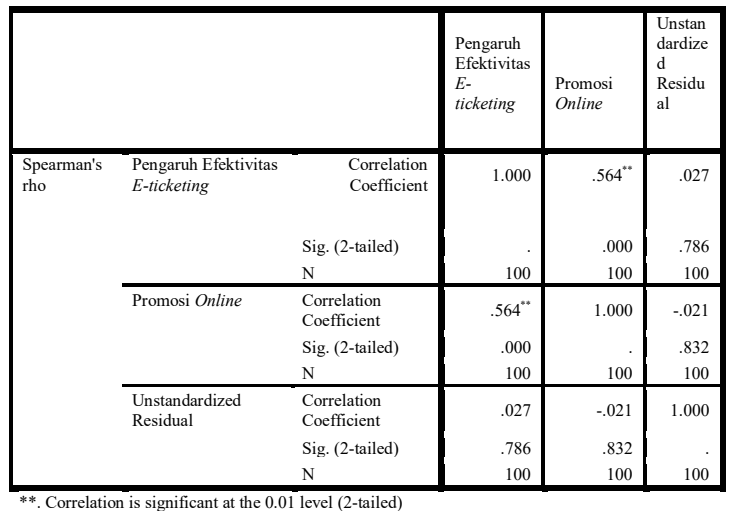

Pada tabel di atas menunjukkan bahwa korelasi antara pengaruh efektivitas $e$ ticketing dan unstandardized residual menghasilkan nilai signifikansi 0.786 dan korelasi antara promosi online dengan unstandardized residual menghasilkan nilai signifikansi 0.832, dapat ditarik kesimpulan bahwa pada model regresi tidak ditemukan adanya masalah heteroskedastisitas, karena nilai signifikasi korelasi lebih besar dari 0.05 .

7. Uji Hipotesis secara Parsial

Tabel 7

Hasil Uji t Variabel

Pengaruh Efektivitas E-ticketing

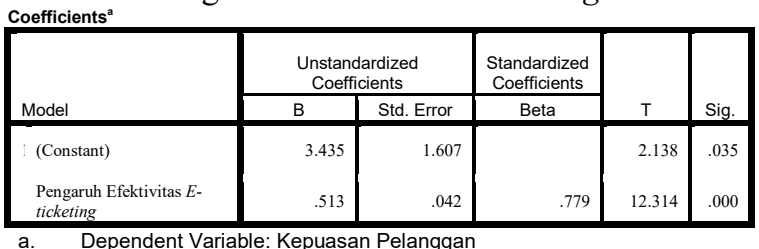

Berdasarkan tabel di atas dapat dilhat bahwa thitung untuk variabel pengaruh efektivitas e-ticketing sebesar 12.314, kemudian dibandingkan dengan 1. Dimana $n$ adalah jumlah sampel dan $\mathrm{k}$ adalah jumlah variabel bebas berdasarkan perhitungan 
tersebut didapat $t_{\text {tabel }}$ sebesar 1.984. Ini berarti $t_{\text {hitung }}>t_{\text {tabel. }}$.

Dari hasil tersebut dapat disimpulkan $\mathrm{H}_{\mathrm{o}}$ ditolak dan $\mathrm{H}_{\mathrm{a}}$ diterima. Hipotesis adalah pengaruh efektivitas e-ticketing memiliki pengaruh positif dan signifikan terhadap peningkatan volume penjualan

Tabel 8

Hasil Uji t Variabel Promosi Online Coefficients $^{\mathrm{a}}$

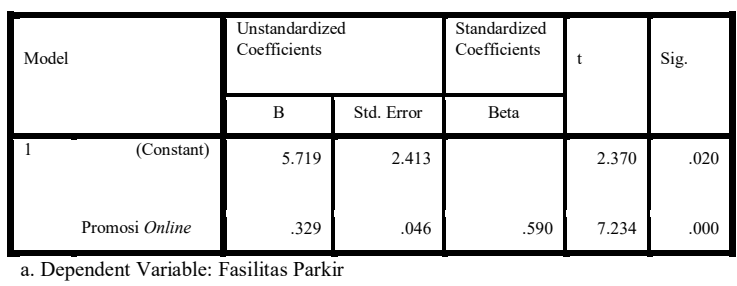

Uraian dari model persamaan tersebut, jika variabel promosi online $\left(\mathrm{X}_{2}\right)$ bernilai 0 , maka variabel peningkatan volume penjualan (Y) akan bernilai 5.719 artinya, jika variabel promosi online $\left(\mathrm{X}_{2}\right)$ ditingkatkan sebesar 0.329 koefisien bernilai positif yang berarti terjadi pengaruh positif antara promosi online dengan peningkatan volume penjualan.

8. Uji Hipotesis secara simultan

Tabel 9

\section{Hasil Uji Hipotesis secara simultan}

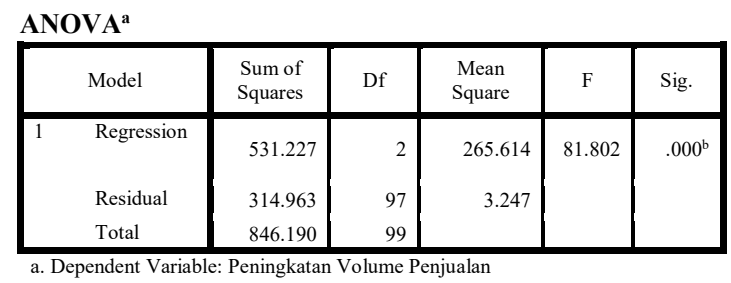

b. Predictors: (Constant), Promosi Online, Pengaruh Efektivitas E-ticketing

Berdasarkan tabel 4.48. didapat nilai $\mathrm{F}_{\text {hitung }}$ sebesar 81.802, nilai $F_{\text {hitung }}$ kemudian dibandingkan dengan nilai $\mathrm{F}_{\text {tabel }}$ yang dicari dengan tingkat keyakinan $95 \% \square=5 \%$ dengan df 1 (jumlah variabel-1) atau 3-1 = 2 dan df 2 (n-k-1) atau 100-2-1 = 98, berdasarkan perhitungan tersebut didapat $F_{\text {tabel }}$ adalah 3.090. Dengan demikian $F_{\text {hitung }}>$ $\mathrm{F}_{\text {tabel, }}$ dan signifikasi pada uji $\mathrm{F}$ sebesar 0.000 , dengan demikian $0.000<0.005$ dapat ditarik kesimpulan Ho ditolak dan $\mathrm{Ha}$ diterima. Hipotesis adalah pengaruh efektivitas e-ticketing dan promosi online secara bersama sama (simultan) memiliki pengaruh positif terhadap peningkatan volume penjualan Citilink di Bandara Halim Perdanakusuma

\section{PEMBAHASAN}

Sesuai hasil analisis dan pengujian yang dilakukan sebagaimana tersebut diatas, secara umum jika dilihat dari karakteristik responden berdasarkan jenis kelamin mayoritas laki-laki sebanyak $61 \%$, berdasarkan usia mayoritas antara 20-50 tahun sebanyak $66 \%$. Berdasarkan domisili/tempat tinggal mayoritas bertempat tinggal Jakarta sebanyak $60 \%$, berdasarkan pendidikan mayoritas S1 sebanyak $71 \%$, berdasarkan pekerjaan mayoritas berprofesi sebagai swasta sebanyak $71 \%$, berdasarkan penghasilan mayoritas berpenghasilan antara Rp. 2.000 .000 - Rp. 5.000.000/bulan sebanyak $43 \%$, berdasarkan alasan penggunaan jasa penerbangan mayoritas karena tugas kantor sebanyak $75 \%$, berdasarkan jumlah penggunaan jasa penerbangan citilink dalam 1 tahun memilih 1x penggunaan dalam 1 tahun sebanyak 
71\%, berdasarkan sumber informasi mayoritas memilih informasi dari keluarga/relasi sebanyak 48\%, berdasarkan pemilihan cara pembelian mayoritas memilih tatap muka sebanyak $34 \%$.

\section{a. Pengaruh Efektivitas E-ticketing $\left(X_{1}\right)$}

Berdasarkan distribusi responden: menggunakan smartphone/ komputer untuk mendapat informasi tiket Citilink secara online diberbagai situs menyatakan setuju sebesar $41 \%$. Berdasarkan distribusi responden: terbantu dengan sistem e-ticketing ketika saya butuh dapat dengan cepat melakukan pembelian via smartphone/computer yang menyatakan setuju sebesar $58 \%$. Berdasarkan distribusi responden: mudah mendapatkan informasi promo dan discount Citilink yang menyatakan setuju sebesar 58\%. Berdasarkan distribusi responden: e-ticketing Citilink di website Citilink/website lainnya memudahkan melakukan reservasi online yang menyatakan setuju sebesar $41 \%$. Berdasarkan distribusi responden: e-ticketing menghemat uang bila dibandingkan membeli langsung di counter yang menyatakan setuju sebesar 33\%. Berdasarkan distribusi responden: dapat mencetak bukti tiket yang dikirim via email yang menyatakan setuju sebesar $39 \%$. Berdasarkan distribusi responden: hanya dengan menunjukkan code booking via smartphone dapat langsung digunakan sebagai bukti check in yang menyatakan setuju sebesar $47 \%$. Berdasarkan distribusi responden: melakukan pembayaran e-ticketing langsung dari smartphone dengan kartu kredit/ATM yang menyatakan setuju sebesar 54\%. Berdasarkan distribusi responden: saya menerima email bukti code booking dari Citilink via smartphone yang menyatakan setuju sebesar $47 \%$. Berdasarkan distribusi responden pengaruh efektifitas $e$ ticketing mayoritas menyatakan setuju yaitu sebanyak 8 dari total 9 distribusi pernyataan responden atau $88,89 \%$ dari total secara keseluruhan responden. Selanjutnya berdasarkan uji linearitas variabel pengaruh efektivitas e-ticketing dan variabel peningkatan volume penjualan memiliki hubungan yang linear dengan nilai signifikan sebesar 0.000 lebih kecil dari 0.05 dan nilai signifikansi deviasi from linearity data tersebut adalah sebesar 0.359 lebih besar dari 0.05 . Kemudian berdasarkan uji homogenitas maka variabel pengaruh efektivitas $e$ ticketing dan variabel peningkatan volume penjualan mempunyai nilai signifikasi 0.183 lebih besar dari 0.05 dari yang disyaratkan, artinya data variabel Peningkatan Volume Penjualan mempunyai varian yang sama (homogen). Berdasarkan uji $\mathrm{t}$ variabel pengaruh efektivitas e-ticketing memiliki nilai $t_{\text {hitung }}>t_{\text {tabel }}$ yaitu sebesar $12.314>1984$ selanjutnya nilai signifikasi sebesar 0.00 lebih kecil dari nilai yang dipersyaratkan yaitu sebesar 0.05, artinya pengaruh efektivitas e-ticketing memiliki pengaruh positif dan signifikan terhadap peningkatan volume penjualan Citilink di Bandara Halim 
Perdanakusuma. Berdasarkan uji koefisien Determinasi $\left(\mathrm{R}^{2}\right)$ persentase pengaruh variabel efektivitas e-ticketing terhadap peningkatan volume penjualan sebesar 0.607 atau $60,7 \%$, sedangkan $39,3 \%$ sisanya dipengaruhi oleh variabel lain yang tidak dilibatkan pada model persamaan regresi linear sederhana untuk hipotesis tersebut, sementara itu nilai adjusted $\mathrm{R}^{2}$ sebesar 0.607. Berdasarkan uji korelasi sederhana (r) didapat korelasi antara pengaruh efektivitas e-ticketing dengan peningkatan volume penjualan dengan $\mathrm{r}$ adalah 0.779 . Hal ini menunjukkan bahwa terjadi hubungan yang kuat antara efektivitas e-ticketing dengan peningkatan volume penjualan. Sedangkan arah hubungan adalah positif karena nilai $r$ positif, berarti semakin tinggi efektivitas $e$ ticketing semakin meningkatkan volume penjualan.

\section{b. Pengaruh Promosi Online $\left(\mathrm{X}_{2}\right)$}

Berdasarkan distribusi responden: Mudah mengakses website Citilink co.id tentang iklan destinasi wisata untuk memperoleh informasi harga, jadwal penerbangan dan tempat tujuan wisata yang menyatakan setuju sebesar $\quad 46 \%$. Berdasarkan distribusi responden: mudah untuk mengakses website lainnya yang menampilkan iklan penerbangan citilink seperti traveloka.com dan tiket.com yang menyatakan setuju sebesar 57\%. Berdasarkan distribusi responden: terkesan dengan pantun yang diberikan pada saat pesawat Citilink akan mendarat yang menyatakan setuju sebesar $45 \%$. Berdasarkan distribusi responden: website Citilink.co.id menampilkan promo discount berbagai penawaran yang menarik yang menyatakan setuju sebesar 55\%. Berdasarkan distribusi responden: pada website Citilink.co.id, bila menjadi member citilink memberikan keuntungan yang menarik yang menyatakan setuju sebesar 44\%. Berdasarkan distribusi responden: Citilink memberikan reward points bagi konsumen yang membayar menggunakan kartu kredit dan debit yang menyatakan setuju sebesar 49\%. Berdasarkan distribusi responden: Citilink memberikan penawaran menarik dengan mengadakan kuis via sosial media yang menyatakan setuju sebesar $42 \%$. Berdasarkan distribusi responden: puas atas layanan konsumen 24 jam cepat dan dapat membantu kesulitan konsumen yang menyatakan setuju sebesar 51\%. Berdasarkan distribusi responden: tertarik ikut membership bila mendapatkan penawaran menarik yang menyatakan setuju sebesar $42 \%$. Berdasarkan distribusi responden: merekomendasikan kepada teman,r ekan bisnis, saudara untuk membeli tiket jasa penerbangan Citilink yang menyatakan setuju sebesar 44\%. Berdasarkan distribusi responden: Citilink menyediakan counter penjualan yang dapat diakses melalui telpon, fax, dan email yang menyatakan setuju sebesar $45 \%$. Berdasarkan distribusi responden: menyediakan layanan penjualan tatap muka yang menyatakan setuju sebesar 
$43 \%$. Berdasarkan distribusi responden: Promosi online dapat diakses melalui sosial media yang menyatakan setuju $45 \%$. Berdasarkan distribusi responden: melakukan pembayaran tiket secara online dengan penggunaan kartu kredit/ATM via smartphone yang menyatakan setuju sebesar $44 \%$. Berdasarkan hasil distribusi responden pengaruh promosi online mayoritas setuju sebanyak 14 dari total 14 distribusi pernyataan responden atau $100 \%$ dari total secara keseluruhan responden. Selanjutnya berdasarkan uji linearitas variabel promosi online dan variabel peningkatan volume penjualan memiliki hubungan yang linear dengan signifikan sebesar 0.000 lebih kecil dari 0.05 dan nilai signifikansi deviasi from linearity data tersebut adalah sebesar 0.992 lebih besar dari 0.05 . Kemudian berdasarkan uji homogenitas maka variabel promosi online $\left(\mathrm{X}_{2}\right)$ dan variabel peningkatan volume penjualan (Y) mempunyai nilai signifikasi 0.621 lebih besar dari 0.05 dari yang disyaratkan, artinya data variabel peningkatan volume penjualan (Y) berdasarkan variabel promosi online $\left(\mathrm{X}_{2}\right)$ mempunyai varian yang sama (homogen). Berdasarkan uji t variabel promosi online memiliki nilai $7.234 \mathrm{t}_{\text {hitung }}>\mathrm{t}_{\text {tabel }} 1.984$ yaitu sebesar $12.314>1984$ selanjutnya nilai signifikasi sebesar 0.000 , dengan demikian lebih kecil dari 0.05 yang dipersyaratkan, artinya promosi online memiliki pengaruh positif dan signifikan terhadap peningkatan volume penjualan citilink di Bandara Halim
Perdanakusuma. Berdasarkan uji koefisien Determinasi $\left(\mathrm{R}^{2}\right)$ persentase pengaruh variabel promosi online terhadap peningkatan volume penjualan sebesar $34,8 \%$ sedangkan $65,2 \%$ sisanya dipengaruhi oleh variabel lain yang tidak dilibatkan dalam model persamaan regresi linear sederhana untuk hipotesis tersebut. Sementara itu, nilai adjusted $\mathrm{R}^{2}$ sebesar 0.348. Berdasarkan uji korelasi sederhana (r) didapat korelasi antara promosi online dengan peningkatan volume penjualan dengan $\mathrm{r}$ adalah 0.590 . Hal ini menunjukkan bahwa terjadi hubungan yang sedang antara promosi online dengan peningkatan volume penjualan. Sedangkan arah hubungan adalah positif karena nilai $r$ positif, berarti semakin tinggi promosi online semakin meningkatkan volume penjualan.

\section{c. Pengaruh Efektivitas E-ticketing dan \\ Promosi Online terhadap Peningkatan Volume Penjualan.}

Berdasarkan distribusi responden: untuk memilih jasa penerbangan Citilink dibandingkan jasa penerbangan lainnya yang menyatakan setuju sebesar 53\%. Berdasarkan distribusi responden: Citilink adalah salah satu jasa penerbangan tiket biaya murah dan berkualitas yang menyatakan setuju sebesar $66 \%$. Berdasarkan distribusi responden: dengan e-ticketing dan promosi online dapat mengurangi biaya cetak tiket dan promosi yang menyatakan setuju sebesar 62\%. Berdasarkan distribusi responden: pengurangan biaya cetak tiket dan promosi berarti mengurangi pengeluaran perusahaan, 
menekan harga tiket dan meningkatkan pendapatan yang menyatakan setuju sebesar 46\%. Berdasarkan distribusi responden: merekomendasikan kepada teman dan saudara untuk memilih jasa penerbangan Citilink pada setiap perjalanan udara mereka yang menyatakan setuju sebesar $49 \%$. Berdasarkan distribusi responden peningkatan volume penjualan, mayoritas menyatakan setuju yaitu 5 dari total 5 pernyataan responden atau $100 \%$ dari total keseluruhan responden. Selanjutnya berdasarkan uji normalitas pada penelitian ini menggunakan Uji histogram dan uji normal P Plot. Uji normalitas maka data variabel pengaruh efektivitas, promosi online dan peningkatan volume penjualan dinyatakan memenuhi syarat normalitas dapat dideteksi dengan melihat penyebaran data (titik) pada sumbu diagonal dari grafik atau dengan melihat histogram residualnya. Jadi jika data menyebar disekitar garis diagonal dan mengikuti arah garis diagonal atau grafik histogramnya menunjukkan pola distribusi normal, maka model regresi memenuhi asumsi normal. Berdasarkan uji multikolinearitas, maka variabel pengaruh efektivitas e-ticketing dan promosi online menyatakan bahwa tidak adanya multikolinearitas dengan nilai VIF sebesar 1.600 lebih kecil dari 10.00 kurang dari nilai yang disyaratkan dan nilai tolerance pengaruh efektivitas e-ticketing $\left(\mathrm{X}_{1}\right)$ dan promosi online $\left(\mathrm{X}_{2}\right)$ yakni 0.863 lebih besar dari 0.10 , sehingga dapat disimpulkan tidak terjadi

multikolinearitas.

Uji

Heteroskedastisitas korelasi antara pengaruh efektivitas e-ticketing dan unstandardized residual menghasilkan nilai signifikansi 0.786 dan korelasi antara promosi online dengan unstandardized residual menghasilkan nilai signifikansi 0.832 , dapat ditarik kesimpulan bahwa pada model regresi tidak ditemukan adanya masalah heteroskedastisitas, karena nilai signifikasi korelasi lebih besar dari 0.05. Berdasarkan uji autokolinearitas, variabel pengaruh efektivitas e-ticketing dan variabel promosi online dengan runs test hasil nilai Asymp.Sig. (2 tailed) sebesar 0.228 lebih besar $>0.05$ maka dapat disimpulkan tidak terdapat gejala atau masalah autokorelasi. Berdasarkan uji $\mathrm{F}$ variabel pengaruh efektivitas e-ticketing dan variabel promosi online memiliki nilai nilai $\mathrm{F}_{\text {hitung }}$ sebesar 81.802, nilai $\mathrm{F}_{\text {hitung }}$ kemudian dibandingkan dengan nilai $F_{\text {tabel }}$ adalah 3.090. Dengan demikian $F_{\text {hitung }}>F_{\text {tabel, }}$ dan signifikasi pada uji F sebesar 0.000 , dengan demikian 0.000 $<0.005$ dapat ditarik kesimpulan Ho ditolak dan Ha diterima. Hipotesis adalah pengaruh efektivitas e-ticketing dan promosi online secara bersama sama (simultan) memiliki pengaruh positif terhadap peningkatan volume penjualan tiket Citilink di Bandara Halim Perdanakusuma. Kemudian berdasarkan uji koefisien determinasi, secara simultan prosentase pengaruh efektivitas $e$ ticketing dan promosi online terhadap peningkatan volume penjualan yaitu sebesar 
sebesar 0.620, dengan demikian variabel pengaruh efektivitas e-ticketing dan promosi online secara simultan memiliki persentase pengaruh terhadap peningkatan volume penjualan sebesar $62,8 \%$ sisanya $37,2 \%$ dipengaruhi oleh variabel lainnya yang tidak dilihat dalam model persamaan regresi linear berganda tersebut. Sementara itu, nilai adjusted $\mathrm{R}^{2}$ sebesar 0.628 .

\section{KESIMPULAN}

Berdasarkan atas kajian analisis data pada Bab IV serta kajian teoritis maka dapat ditarik kesimpulan dari hasil penelitian ini:

1. Berdasarkan hasil uji $\mathrm{t}$ diperoleh: $\mathrm{Y}^{1}=$ $3.435+0.513 \mathrm{X}_{1}$ menunjukkan bahwa pengaruh efektivitas e-ticketing secara parsial terhadap peningkatan volume penjualan yaitu sebesar $51,3 \%$,

2. Berdasarkan hasil uji $\mathrm{t}$ diperoleh: $\mathrm{Y}^{1}=$ $5.719+0.329 \mathrm{X}_{2}$ menunjukkan bahwa pengaruh promosi online secara parsial terhadap peningkatan volume penjualan yaitu sebesar $32,9 \%$.

3. Berdasarkan hasil uji $\mathrm{F}$ diperoleh: $\mathrm{Y}=$ $0.909+0.404 \mathrm{X}_{1}+0.101 \mathrm{X}_{2}$ menunjukkan bahwa pengaruh efektivitas e-ticketing dan promosi online secara simultan terhadap peningkatan volume penjualan yaitu sebesar $90,9 \%$.

\section{SARAN}

1. Berdasarkan hasil uji t pada efektivitas e-ticketing secara parsial terhadap peningkatan volume penjualan yaitu sebesar $51,3 \%$, agar pengaruh efektivitas e-ticketing berdampak positif dan signifikan kami memberikan saran kepada Citilink untuk melakukan sosialisasi di ruang tunggu pesawat, melalui media tv/radio dan cetak agar masyarakat familiar menggunakan aplikasi e-ticketing Citilink.

2. Berdasarkan hasil Uji t pada promosi online secara parsial terhadap peningkatan volume penjualan yaitu sebesar $32,9 \%$, agar pengaruh promosi online maksimal terhadap peningkatan volume penjualan kami memberikan saran untuk meningkatkan fasilitas search enginee yang memudahkan masyarakat untuk melacak dengan cepat promo penerbangan Citilink.

\section{DAFTAR PUSTAKA}

Arikunto, Suharsimi. 2006. Metodologi penelitian. Yogyakarta: Bina Aksara.

Andre Hardjana,2000:24. Audit komunikasi: Teori dan Praktek, ISBN 979-669809-9. Grasindo, Jakarta.

Effendy, Onong Uchjana,2006. Ilmu Komunikasi Teori dan Praktek, PT.Remaja Rosdakarya. Bandung.

eWolf Community. 2012. "Panduan Internet Paling Gampang". Yogyakarta: Cakrawala 
Ghozali, 2011:52. Ghozali, Imam. 2011. Aplikasi Analisis Multivariate Dengan Program SPSS 20. Semarang : Badan Penerbit Universitas Diponegoro.

Herlambang, S. (2014). Basic Marketing, Cara Mudah Memahami Ilmu Pemasaran. Yogyakarta: Gosyen Publishing.

Hardjana, Andre. 2000. Audit Komunikas $\mathrm{i}$ : Teori dan Praktek. ISBN: 979669-809-9 PT. Grasindo. Jakarta.

Hasil survei yang dilakukan oleh International Air Transport Association (IATA) Penggunaan $e$ ticketing di Indonesia www.iata.org, survey highlights edition 2016.

Jumlah Penumpang Jasa Penerbangan Indonesia di Bandara Halim Perdanakusuma Tahun 2011-2015, diambil dari angkasa pura II.

Kotler, P. \& Keller, K. L. (2012). Marketing Management (14th ed.). United States of America: Pearson.

Kamus Besar Bahasa Indonesia edisi ketiga tahun buku 2003 halaman 284 yang disusun oleh Pusat Bahasa Indonesia, Departemen Pendidikan Nasional

Kasali, R., 2011. Cracking zone: Bagaimana Memetakan Perubahan Di Abad Ke21 \& Keluar Dari Perangkap Comfort Zone. Jakarta: PT Gramedia Pustaka Utama.

Nicholas Bienz. Electronic Business Course - SA 2008, Project: E-Ticketing. Univeristy of Friburgensis, Mei 2008.

Nova, R. (2012). Manajemen Kompensasi. Bandung: Karya Putra darwati.

Rambat Lupiyoadi,2014. Manajemen Pemasaran Jasa berbasis Kompetensi, ISBN 978-979-061-259-4, Salemba Empat, Jakarta.
Sugiyono, 2010. Metode Penelitian Bisnis, ISBN 978-979-8433-24-5. Alfabeta, Bandung.

Swastha, Basu dan Irawan, 2000, Manajemen Pemasaran Modern, (Edisi II, Get. VHI),: Liberty Yogyakarta.

Uma Sekaran. 2006. Metode Penelitian Bisnis. Jakarta : Salemba Empat.

Yuhefizar, 2008. 10 Jam menguasai internet teknologi dan aplikasinya, PT. Elex Media Kompatindo. Jakarta.

Yet, S. (2011). Start Marketing. Jakarta: PT. Gramedia Pustaka Utama. 